\title{
Deterministic and probabilistic approaches to the denomination of the hydrochemical type of potentially medicinal groundwater from the "Zdrój Główny” intake (Krzeszowice, Poland)
}

\author{
Piotr Rusiniak ${ }^{1}$, Katarzyna Wątor ${ }^{1}$ Janusz Plata ${ }^{2}$ \\ ${ }^{1}$ AGH University of Science and Technology, Faculty of Geology, Geophysics and Environmental Protection, Department of \\ Hydrogeology and Engineering Geology; al. A. Mickiewicza 30,30-059 Krakow, Poland; e-mail: piotr.rusiniak@agh.edu.pl \\ ${ }^{2}$ The Centre for Rehabilitation of Organ Movement "Krzeszowice" SP ZOZ; ul. Daszyńskiego 1, 32-065 Krzeszowice, Poland
}

(C) 2017 Authors. This is an open access publication, which can be used, distributed and reproduced in any medium according to the Creative Commons CC-BY 4.0 License requiring that the original work has been properly cited.

Received: 13 June 2017; accepted: 02 January 2018

\begin{abstract}
The analysis and quality control of potentially curative water in Krzeszowice (Lesser Poland Region, Poland) has been carried out since 2002. The analyses are performed in the certified Hydrogeochemical Laboratory of the AGH University of Science and Technology and the laboratory of Provincial Environmental Protection Inspectorate in Krakow. The main purpose of this paper was to confirm the denomination of the hydrochemical type of water taken from "Zdrój Główny" both for major ions and sulphur(II) compounds concentration which are specific components and assign curative properties to the examined water. On the basis of statistical analysis, it was stated that the concentrations of $\mathrm{SO}_{4}, \mathrm{Ca}, \mathrm{Mg}, \mathrm{HCO}_{3}$ and sulphur(II) compounds can be regarded as stable. Different methods of hydrochemical type determination lead to various classifications of groundwater. In the deterministic method and the probabilistic method with use of expanded uncertainty, the hydrochemical type of the examined water is $\mathrm{SO}_{4}$-Ca-Mg, $\mathrm{S}$. In the probabilistic method where the standard deviation was taken into account, fewer components were in the hydrochemical type $\left(\mathrm{SO}_{4}-\mathrm{Ca}\right)$-sulphur(II) compounds did not exceed the threshold value of $1 \mathrm{mg} / \mathrm{L}$ and, in this situation, the water cannot be regarded as potentially curative.
\end{abstract}

Keywords: medicinal qualities, Krzeszowice, hydrochemical type, deterministic and probabilistic method

\section{INTRODUCTION}

The criteria of assessment of the medicinal qualities of groundwater are described in two Polish regulations: Geological and Mining Law (Obwieszczenie 2016) and Regulation of the Minister of Health (Rozporządzenie 2006).

According to Obwieszczenie (2016), groundwater can be classified as a curative water if it is not contaminated biologically and chemically and it is characterized by the natural variability of its physical and chemical parameters.
In case of the water of "Zdrój Główny", the main criterion determining the medicinal status of this water is not only its high mineralization at about $3 \mathrm{~g} / \mathrm{L}$, but also the concentration of sulphur(II) compounds exceeding $1 \mathrm{mg} / \mathrm{L}$ (Tomaszewska et al. 2007).

In this paper, the results of the stability of both of the ions determining the hydrochemical type of water of "Zdrój Główny" - constituting at least $20 \%$ meq of the total sum of cations and anions and of sulphur(II) compounds as a specific component of investigated water (Rozporządzenie 2006) 
were presented. Also, the assessment confirming the curative character of groundwater taken from "Zdrój Główny" using the deterministic and probabilistic method was made.

\section{MATERIALS AND METHODS}

The main object of conducted research is the potentially curative sulphurous mineral water taken from "Zdrój Główny” located in Krzeszowice town, Lesser Poland Voivodeship, county of Krzeszowice, Krzeszowice commune. The studied site is situated about 25 kilometres west of Krakow (Fig. 1). The "Zdrój Główny" takes its curative water from the Neogene aquifer (Tomaszewska 2003, 2007).

In the study area there are three water-bearing horizons: Quaternary, Miocene with specific waters and Jurassic-Cretaceous with mineral waters.

For the purpose of the presented article, only the water horizon within Neogene deposits was discussed. This horizon has an essential importance for the town of Krzeszowice due to the occurrence of potentially medicinal sulphurous mineral water (Tomaszewska et al. 2001, Szczepańska-Plewa et al.
2009). They are located within the gypsum series of lower Tortonian. The environment of water occurrence has a fissure character. The "Zdrój Główny" intake was constructed in 1770 and it has been exploited continuously until the present. The admissible volume of extracted groundwater is $2.33 \mathrm{~m}^{3} / \mathrm{h}$ with drawdown established at the level of $3.40 \mathrm{~m}$. The total depth of the intake is $5.35 \mathrm{~m}$ (Seredyn 1967, Szemioth 1982, Porwisz et al. 2002). On the basis of the geological documentation it was stated that the sulphurous water reservoir is recharged by natural water infiltration throughout Quaternary deposits (shales) to the fissure-karst deposits of the gypsum series (Seredyn 1967, Wagner 2000, Tomaszewska 2002, 2003, Motyka et al. 2003, Milijanović \& Satora 2006, Tomaszewska 2006, 2007, Tomaszewska et al. 2007, Porwisz et al. 2006). The age of the studied water from "Zdrój Główny" is estimated at 8,000 years (early Holocene period). A lack of tritium and very low concentrations of radiocarbon indicated groundwater recharge before 1954, when thermonuclear testing began (Motyka et al. 2003, Milijanović \& Satora 2006, Tomaszewska et al. 2007, Szczepańska-Plewa et al. 2009, Skrzypczak 2012).

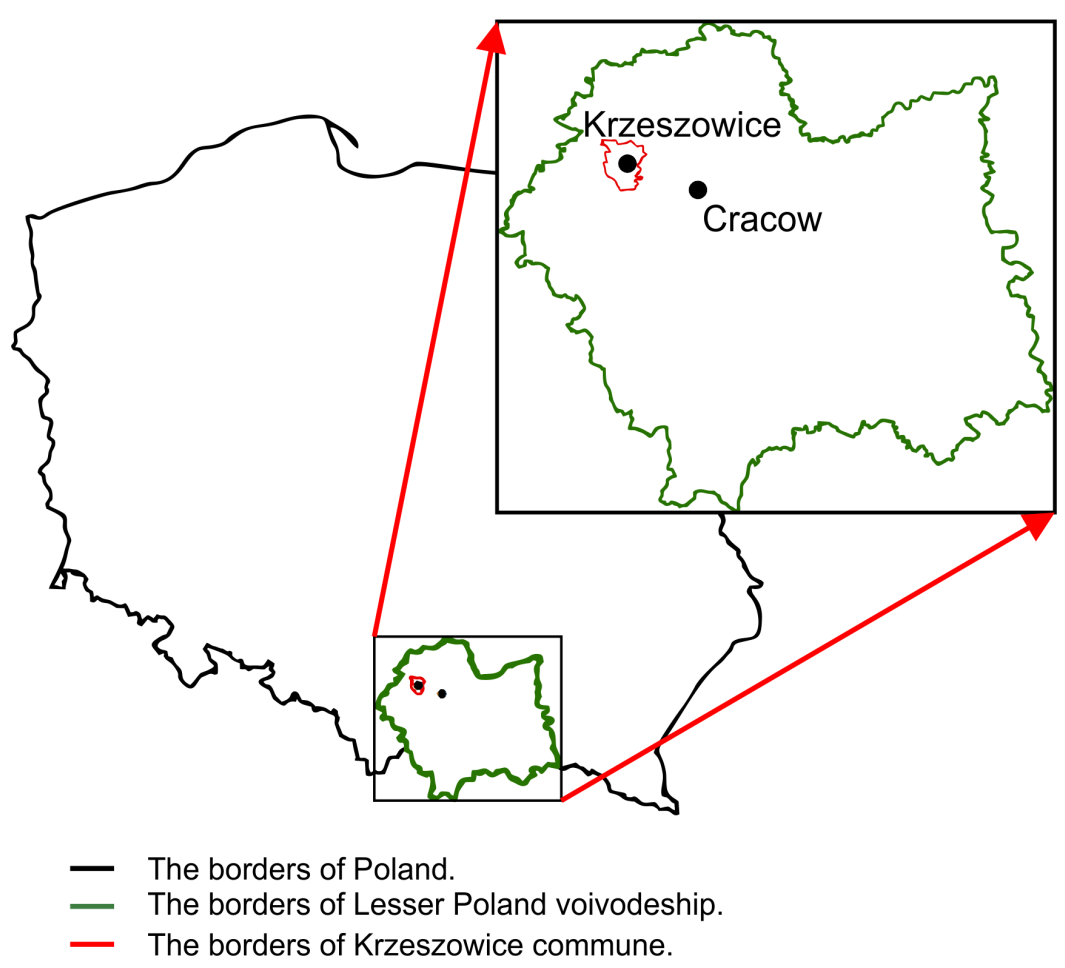

Fig. 1. Location of the Krzeszowice town 
Water samples are collected according to PNEN ISO 5667 norm series by one sampler, once a month. Samples for cations analyses are filtered in the field using microporous filters with a pore diameter of $0.45 \mu \mathrm{m}$ and preserved by the addition of $1 \mathrm{ml}$ of concentrated nitric acid for each $100 \mathrm{ml}$ of water. Water for sulphur(II) compounds determination is placed in a dark glass bottle without air and preserved using Ethylenediaminetetraacetic acid disodium salt dihydrate. The investigations of the water have been conducted by the certified Hydrogeochemical Laboratory (Accreditation certificate No. AB 1050) at the Department of Hydrogeology and Engineering Geology, the Faculty of Geology, Geophysics and Environmental Protection, the AGH University of Science and Technology, Krakow, since 2002 (Porwisz et al. 2006, Tomaszewska et al. 2007). Sulphur(II) compounds were analysed by the laboratory of the Provincial Environmental Protection Inspectorate (PEPI) in Krakow. The analytical methods applied for the determination of components setting the hydrochemical type of water from "Zdrój Główny" are presented in Table 1. Concentrations of sulphates, bicarbonates, sulphur(II) compounds, calcium and magnesium ions were analysed statistically. Listed components are important for determining the hydrochemical type in the case of water taken from the "Zdrój Główny" in Krzeszowice. In total 197 analyses were conducted from 2002 to 2016.

The assessment of curative character is predominantly made using the deterministic method. This method is based on the comparison of mean concentrations of analysed parameters with threshold values presented in Obwieszczenie (2016) or Rozporządzenie (2006) law regulations. The second possibility is to use the probabilistic method (Ciężkowski red. 2007) where the mean values of potentially curative parameters, reduced by two standard deviations, are compared with the threshold values (Wątor 2015, Wator et al. 2016). The other variant of the probabilistic method uses the measurement uncertainty. In this approach, the assessment is carried out based on the mean concentrations of parameters reduced by the uncertainty declared by the laboratory conducting analyses. The information about measurement uncertainty is a part of the quality system complied with under PN-EN ISO/IEC 17025:2005. If the decision about the creditability of obtained results is based on the uncertainty or if the uncertainty is related to specific threshold values, the information about uncertainty should be included in a research report (PN-EN ISO/IEC 17025:2005, Kmiecik 2011, Wątor 2015).

Table 1

The analytical methods of ions determination of water from "Zdrój Główny" in Krzeszowice

\begin{tabular}{|c|c|c|c|c|c|c|c|}
\hline Laboratory & Component & \multicolumn{2}{|c|}{ Analytical methods } & \multicolumn{2}{|c|}{$\begin{array}{l}\text { Determination } \\
\text { limit }[\mathrm{mg} / \mathrm{L}]\end{array}$} & \multicolumn{2}{|c|}{$\begin{array}{c}\text { Expanded } \\
\text { uncertainty }{ }^{\star}[\%]\end{array}$} \\
\hline \multirow{4}{*}{ AGH } & Calcium, $\mathrm{Ca}^{2+}$ & \multirow{3}{*}{$\begin{array}{c}\text { PN-EN ISO } \\
\text { 11885:2009 } \\
\text { Inductively } \\
\text { coupled plasma } \\
\text { atomic emission } \\
\text { spectrometry }\end{array}$} & \multirow{3}{*}{$\begin{array}{c}\text { PN EN ISO } \\
\text { 17294:2-2006 } \\
\text { Inductively } \\
\text { coupled } \\
\text { plasma mass } \\
\text { spectrometry }\end{array}$} & 10 & 0.05 & 12 & 12 \\
\hline & Magnesium, $\mathrm{Mg}^{2+}$ & & & 0.1 & 0.001 & 12 & 12 \\
\hline & Sulphates, $\mathrm{SO}_{4}^{2-}$ & & & 3 & 1.0 & 12 & 12 \\
\hline & Bicarbonates, $\mathrm{HCO}_{3}^{-}$ & \multicolumn{2}{|c|}{$\begin{array}{l}\text { PN-EN ISO 9963-1:2001+Ap1:2004 } \\
\text { Titration method }\end{array}$} & \multicolumn{2}{|c|}{24.4} & \multicolumn{2}{|c|}{5} \\
\hline PEPI & $\begin{array}{l}\text { Sulphur (II) } \\
\text { compounds } \\
\left(\mathrm{H}_{2} \mathrm{~S}, \mathrm{HS}^{-}, \mathrm{S}^{2-}\right)\end{array}$ & \multicolumn{2}{|c|}{$\begin{array}{l}\text { PN-82/C-04566/03 } \\
\text { Thiomercurimetric method }\end{array}$} & \multicolumn{2}{|c|}{0.04} & \multicolumn{2}{|c|}{20} \\
\hline
\end{tabular}

* The uncertainty not include sampling, expansion coefficient $k=2.95 \%$.

\section{RESULTS AND DISCUSSION}

The first step was the verification of data distribution and the elimination of outliers when the data distribution was different than normal.
The statistical analysis procedure is presented by Szczepańska-Plewa et al. (2009). Analysis was made with the use of PS IMAGO solution (based on IBM SPSS Statistics pro gramme). 
The analysis of data distribution was conducted for the component concentration in a mass concentration unit $[\mathrm{mg} / \mathrm{L}]$, because the concentrations of individual ions expressed as percent of milliequivalents [\% meq] are strongly dependent on the sum of the cations or anions, respectively. A significance value lower than 0.05 indicates that the data are not normally distributed and this situation concerns sulphates, magnesium ions, bicarbonates and sulphur(II) compounds. For the identification of the outliers, box-and-whisker plots were used. Some of the observations were eliminated to transform the data into a normal distribution which is needed during an analysis using control charts.

In the case of sulphates, the number of eliminated observations is 2. For the calcium ions and bicarbonates, only one observation was excluded from further analysis. The biggest number of rejected outliers were in the case of the magnesium ions -6 observations, and the sulphur(II) compounds -5 observations. After the outliers were removed, all of the analysed parameters are characterized by a normal distribution.

The next step in the statistical analysis was the stability assessment of investigated parameters using the control charts of single measurements in accordance with the methodology presented by Szczepańska \& Kmiecik (2005).

The control charts of single measurement for the sulphates, magnesium ions, calcium ions, sulphur(II) compounds and bicarbonates are shown in Figure 2.

The control charts of single measurements made for the ions appearing in the hydrochemical type of water from "Zdrój Główny" in Krzeszowice indicated only a single signal which exceeded the upper or lower control lines (Fig. 2). In general, the concentration values for sulphates as well as for calcium and magnesium ions are within the range of warning lines. All of the obtained results exceed the threshold value of $20 \%$ meq established in Rozporządzenie (2006), so they should be considered as decisive for the hydrochemical type of investigated water.

In case of the sulphur(II) compounds two single points above the upper control line were observed. Most of the concentration values of this parameter are in the range of. A large number of single concentration values are close to the $1 \mathrm{mg} / \mathrm{L}$ threshold value (Rozporządzenie 2006, Obwieszczenie 2016), so it is necessary to control the stability of this component in the future.

The observed results variation is probably caused by changes in analytical methods used over the years. ICP-OES and ICP-MS methods are used interchangeably in the laboratory. Over such a long period of time, both apparatus and analysts have been changed. What is more, different standard solutions, new calibration curves, sample preparation methods or equipment conservation can bias the final result.

The mean values of the analysed major ions and specific components occurring in the curative water from "Zdrój Główny" were compared with the threshold values formulated in Polish law regulations (Obwieszczenie 2016, Rozporządzenie 2006). The deterministic method and two variants of the probabilistic method were applied (Grath et al. 2006, EURACHEM 2007, PN-ISO 10576-1: 2006, Kmiecik 2011, Wątor et al. 2016).

In the deterministic method (Tab. 2) the mean value of the analysed parameter is directly compared with the threshold value. If the result is lower than the threshold value it means that the analysed component cannot be considered as a specific component of the investigated water. On the other hand, if the obtained result is higher than the threshold value, the analysed parameter should be taken into account during the determination of the hydrochemical type of water.

Table 2

Reference of results of analysis to a threshold values contained in GML (2016) and RMH (2006) in the deterministic and two variants of probabilistic method

\begin{tabular}{|l|c|c|c|c|}
\hline \multicolumn{1}{|c|}{ Component } & Threshold values & $\bar{x}$ & $\bar{x}-2 s$ & $\bar{x}-2 U$ \\
\hline $\mathrm{SO}_{4}^{2-}[\% \mathrm{meq}]$ & 20 & 80.90 & 76.44 & 71.20 \\
\hline $\mathrm{HCO}_{3}^{-}[\%$ meq] & 20 & 17.36 & 13.01 & 16.50 \\
\hline $\mathrm{Mg}^{2+}[\%$ meq] & 20 & 22.78 & 19.66 & 20.04 \\
\hline $\mathrm{Ca}^{2+}[\%$ meq] & 20 & 72.86 & 69.38 & 64.12 \\
\hline $\mathrm{H}_{2} \mathrm{~S}[\mathrm{mg} / \mathrm{L}]$ & 1 & 3.13 & 0.64 & 2.50 \\
\hline The hydrochemical type & & $\mathrm{SO}_{4}$-Ca-Mg, $\mathrm{S}$ & $\mathrm{SO}_{4}$-Ca & $\mathrm{SO}_{4}$-Ca-Mg, $\mathrm{S}$ \\
\hline
\end{tabular}


A

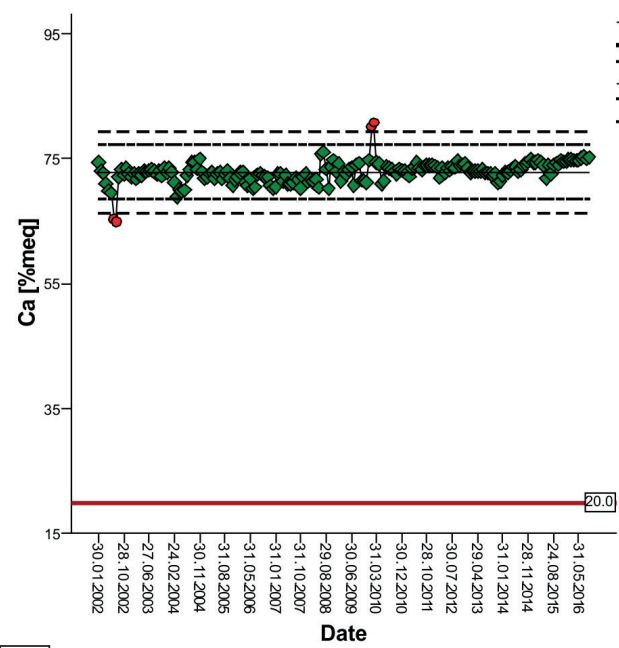

C
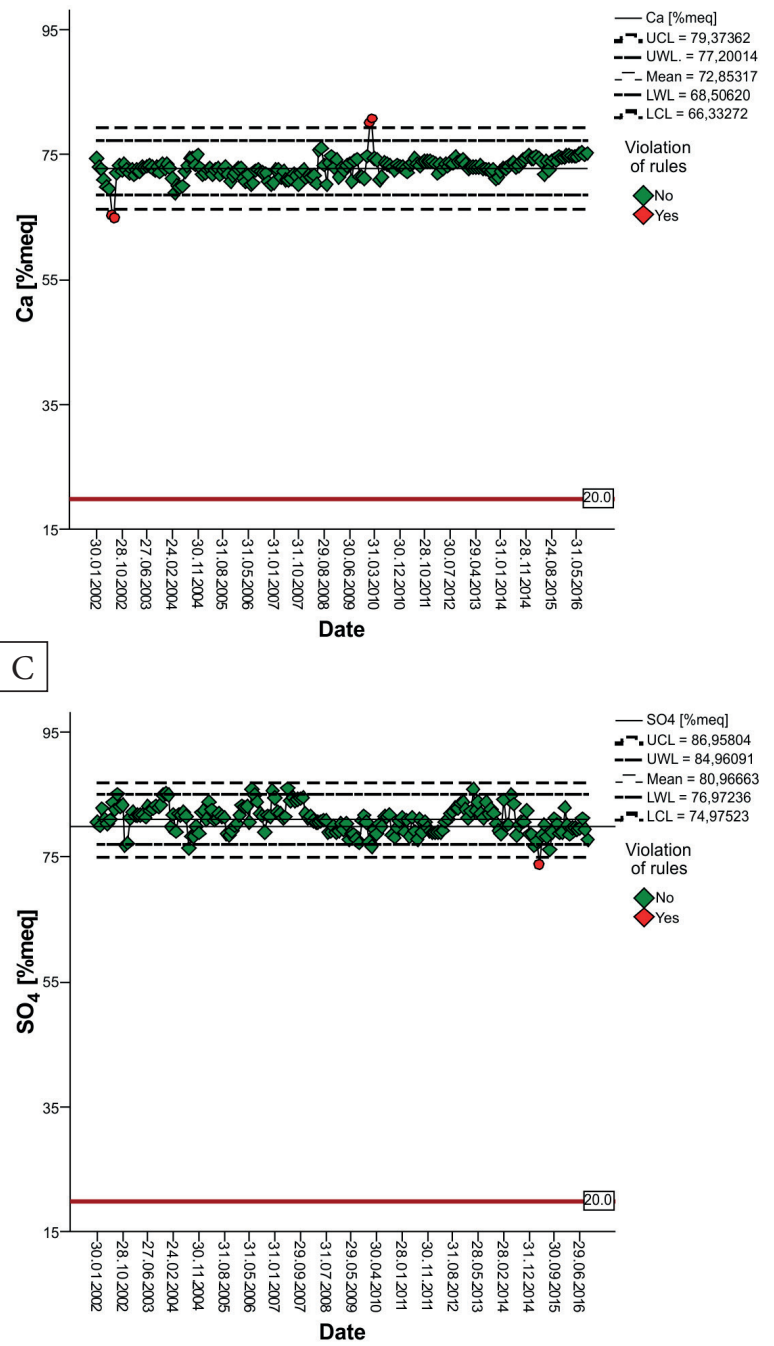

$\mathrm{B}$

(1)

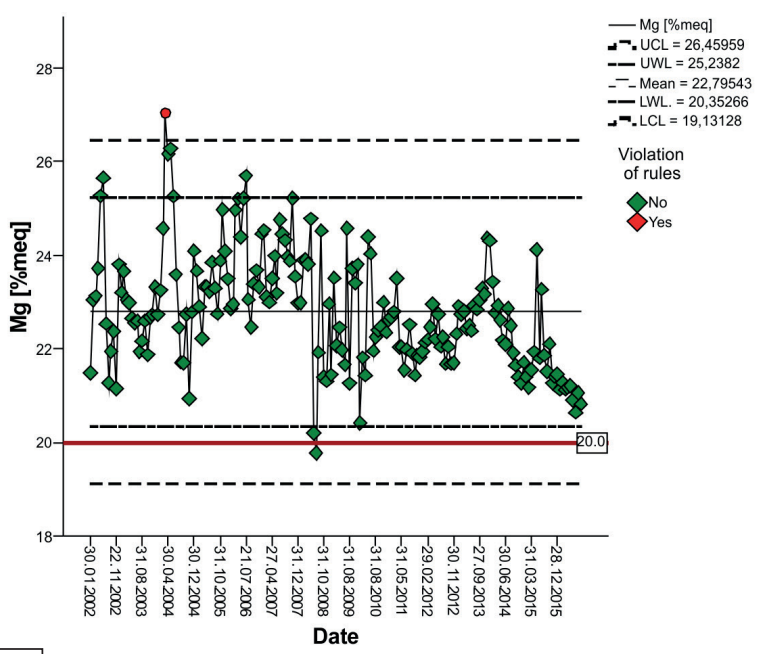

D

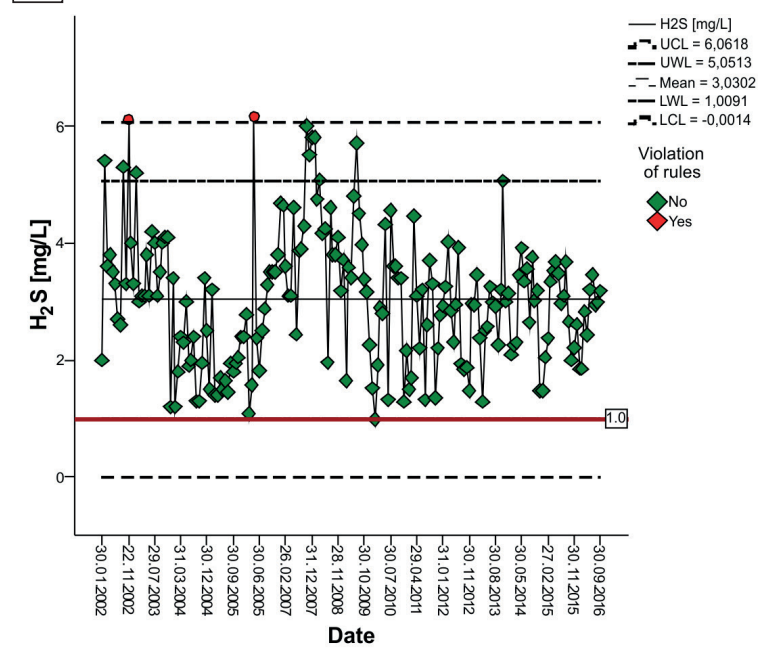

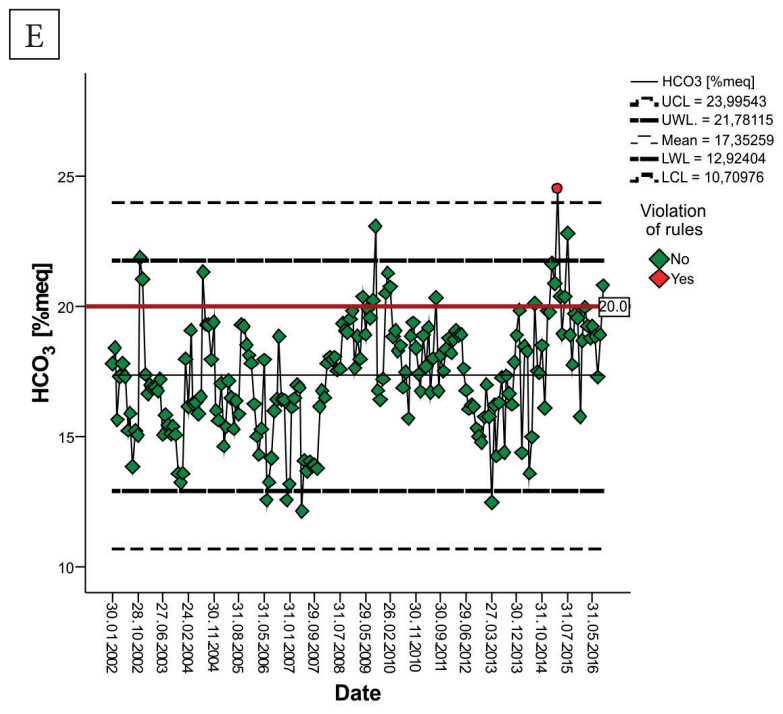

Fig. 2. Control charts of single measurements of sulphates (A), magnesium (B), calcium (C), sulphur(II) compounds (D), bicarbonates $(E)$ 
In the probabilistic method (Tab. 2) two variants were applied. In the first one, proposed by Ciężkowski (red.) (2007), the mean value of the analysed parameter minus two standard deviations (2s) was compared with the threshold value. In the second case, the mean values were decreased by the measurement uncertainty declared by the laboratory performing analyses.

Referring the mean results to the threshold values, it can be observed that only in case of the bicarbonates was the threshold value not exceeded. According to this, bicarbonates cannot be taken into account in the denomination of the hydrochemical type of the studied water. For the other ions, the threshold values were exceeded, so the researched water was classified as $\mathrm{SO}_{4}$-Ca-Mg, $\mathrm{S}$.

In the first variant of the probabilistic method, the mean values of the analysed parameter were decreased by two standard deviations in accordance with the methodology of Ciężkowski et al. (2007). For the bicarbonate and magnesium ions, the threshold values were not exceeded. Based on these results, the investigated water can be classified as $\mathrm{SO}_{4}$-Ca and it should not be classified as sulphurous water.

When the measurement uncertainty declared by the analytical laboratory instead of the standard deviation is taken into account (in pursuance of the methodology proposed by Kmiecik 2011, Wątor 2014, Wątor et al. 2016), the hydrochemical type of studied water is $\mathrm{SO}_{4}$-Ca-Mg, S. For the bicarbonates, the threshold value was not exceeded.

\section{CONCLUSIONS}

Analysis of the stability of the physicochemical parameters of the potentially curative water taken from the "Zdrój Główny" intake in Krzeszowice was presented. Using the PS IMGAO software, the control charts of the single measurements of the ions assigning the hydrochemical type of this water and for the medicinal component - sulphur(II) compounds - were tested.

The analysis of control charts showed that for the all of the analysed ions some single concentrations exceeded the upper or lower control line $(\bar{x}-3 s, \bar{x}+3 s)$. However, the majority of results are situated in the range of warning lines $(\bar{x}-2 s, \bar{x}+2 s)$.
The results showed that the water from "Zdrój Główny" is characterized by a stable chemical composition.

When the deterministic method is used to assess the hydrochemical type of medicinal water, any errors related to sampling and analyses are silently included and affect the outcome. This approach may incorrectly suggest that measurement uncertainty is zero (Demetriades 2010).

During the determination of the hydrochemical type of water, the application of measurement uncertainty instead of standard deviation in the probabilistic approach meant that more components were included in the hydrochemical type of studied water from "Zdrój Główny" in Krzeszowice. The values of standard deviation are strongly dependent on the dispersion of the data. If the dispersion of the results is high, the standard deviation is also high. This situation can result in the nether limit of the variability interval being lower than the threshold value, although the majority of the results exceed the threshold value formulated in legal regulations (Wątor et al. 2016).

The concentration of the main components definitely exceeds the threshold of $20 \%$ meq (Rozporządzenie 2006), and for the specific component - sulphur(II) compounds - $1 \mathrm{mg} / \mathrm{L}$, so the studied mineral water from "Zdrój Główny" in Krzeszowice can be classified as a curative with the hydrochemical type as follow: sulphate-calcium-magnesium, sulphurous $\left(\mathrm{SO}_{4}-\mathrm{Ca}-\mathrm{Mg}, \mathrm{S}\right)$.

The study was partially supported by AGH UST 11.11.140.797.

\section{REFERENCES}

Ciężkowski W. (red.), 2007. Dopuszczalne wahania eksploatacyjnych i fizyczno-chemicznych parametrów wód leczniczych: zasady ustalania. Oficyna Wydawnicza Politechniki Wrocławskiej, Wrocław.

Demetriades A., 2010. Use of measurement uncertainty in a probabilistic scheme to assess compliance of bottled water with drinking water standards. Journal of Geochemical Exploration, 107, 3, 410-422.

EURACHEM, 2007. Use of uncertainty information in compliance assessment. $1^{\text {st }}$ ed.

Grath J., Ward R. \& Quevauviller P., 2006. Monitoring Guidance for Groundwater. Final draft (v. 10.0). Drafting group GW1 Groundwater Monitoring, [on-line:] https:// goo.gl/gLN5uf [access: 18.05.2016]. 
Kmiecik E., 2011. Metodyczne aspekty oceny stanu chemicznego wód podziemnych. Wydawnictwa AGH, Kraków.

Milijanović S. \& Satora S., 2006. Wpływ budowy geologicznej na występowanie wód mineralnych w rowie tektonicznym Krzeszowic. Infrastruktura i Ekologia Terenów Wiejskich, 2/2/2006, 51-64.

Motyka J., Porwisz B., Rajchel L. \& Zuber A., 2003. Wody mineralne Krzeszowic. [in:] Piekarek-Jankowska H. \& Jaworska-Szulc B. (red.), Współczesne problemy hydrogeologii. T. 11, cz. 1, Wydział Budownictwa Wodnego i Inżynierii Środowiska Politechniki Gdańskiej, Gdańsk, 129-135.

Obwieszczenie, 2016. Obwieszczenie Marszałka Sejmu Rzeczypospolitej Polskiej z dnia 1 lipca 2016 r. w sprawie ogtoszenia jednolitego tekstu ustawy - Prawo geologiczne i górnicze. Dz.U. 2016, poz. 1131.

PN-C-04566-03:1982. Woda i ścieki - Badania zawartości siarki i jej związków - Oznaczanie siarkowodoru i siarczków rozpuszczalnych metoda tiomerkurymetryczną. Polski Komitet Normalizacyjny, Warszawa.

PN-EN ISO 5667-11:2004. Jakość wody - Pobieranie próbek Część 11: Wytyczne dotyczace pobierania próbek wód podziemnych. Polski Komitet Normalizacyjny, Warszawa.

PN-EN ISO/IEC 17025:2005. Ogólne wymagania dotyczace kompetencji laboratoriów badawczych $i$ wzorcujacych. Polski Komitet Normalizacyjny, Warszawa.

PN-ISO 10576-1: 2006. Metody statystyczne - Wytyczne oceny zgodności z określonymi wymaganiami - Część 1: Zasady ogólne. Polski Komitet Normalizacyjny, Warszawa.

Porwisz B., Chowaniec J., Gorczyca G. \& Kowalski J., 2002. Dokumentacja hydrogeologiczna zasobów dyspozycyjnych wód leczniczych i towarzyszacych im lub występujacych odrębnie wód potencjalnie leczniczych na obszarze Karpat i zapadliska przedkarpackiego. Przedsiębiorstwo Geologiczne S.A., PIG, Kraków.

Porwisz B., Szczepański A.\& Tomaszewska B., 2006. Charakterystyka i wykorzystanie karpackich wód leczniczych. Gaz, Woda i Technika Sanitarna, 11, 35-38.

Rozporządzenie, 2006. Rozporządzenie Ministra Zdrowia $z$ dnia 13 kwietnia 2006 r. w sprawie zakresu badań niezbędnych do ustalenia właściwości leczniczych naturalnych surowców leczniczych $i$ właściwości leczniczych klimatu, kryteriów ich oceny oraz wzoru świadectwa potwierdzajacego te właściwości. Dz.U. 2006, nr 80, poz. 565.

Seredyn S., 1967. Dokumentacja hydrogeologiczna ujęcia wód siarczkowych z utworów mioceńskich R-2 dla Ośrodka Balneologicznego w Krzeszowicach. Przedsiębiorstwo Geologiczne, Wrocław.

Skrzypczak R., 2012. Wody Krzeszowic: siarczkowa, siarczanowa i krzemowa - współczesny atut najmodniejszego kurortu Polski połowy XIX w. Technika Poszukiwań Geologicznych, Geotermia, Zrównoważony Rozwój, 51, 2, 91-101.
Szczepańska J. \& Kmiecik E., 2005. Ocena stanu chemicznego wód podziemnych w oparciu o wyniki badań monitoringowych. Uczelniane Wydawnictwa Naukowo-Dydaktyczne AGH, Kraków.

Szczepańska-Plewa J., Kmiecik E. \& Drzymała M., 2009. Ocena stabilności składu chemicznego wód leczniczych ze Zdroju Głównego w Krzeszowicach. Biuletyn Państwowego Instytutu Geologicznego, 436, 9/2, 497-506.

Szemioth A., 1982. Dokumentacja hydrogeologiczna w kat. $A+B$ ujęcia siarczanowych wód leczniczych „Zdrój Głów$n y$ " w Krzeszowicach. Przedsiębiorstwo Geologiczne, Kraków.

Tomaszewska B., 2002. Kontrola jakości parametrów hydrogeochemicznych złoża wód leczniczych. WUG: Bezpieczeństwo Pracy i Ochrona Środowiska $w$ Górnictwie, 2, 26-31.

Tomaszewska B., 2003. „Zdrój Główny” w Krzeszowicach. Analiza składu chemicznego wód leczniczych. WUG: Bezpieczeństwo Pracy i Ochrona Środowiska w Górnictwie, 6, 21-24.

Tomaszewska B., 2006. Analiza zmienności wybranych wskaźników chemicznych wód leczniczych w układzie czasowym na przykładzie „Zdroju Głównego” w Krzeszowicach. [in:] Aktualne problemy hydrogeochemii: Hydrogeochemia '06: X międzynarodowa konferencja naukowa, 23-24.06.2006, Sosnowiec-Złoty Potok, Wydział Nauk o Ziemi Uniwersytetu Śląskiego, Katedra Hydrogeologii i Geologii Inżynierskiej, Sosnowiec, 117-119.

Tomaszewska B., 2007. Zmienność zawartości siarczanów, wapnia i magnezu w układzie czasowym w wodach leczniczych „Zdroju Głównego” w Krzeszowicach. WUG: Bezpieczeństwo Pracy i Ochrona Środowiska w Górnictwie, 3, 22-28.

Tomaszewska B., Kmiecik E., Piechowska M. \& Plata J., 2007. Ocena stabilności stężeń siarczanów w czasie w wodach leczniczych ze „Zdroju Głównego” w Krzeszowicach. [in:] Szczepański A., Kmiecik E. \& Żurek A. (red.), Współczesne problemy hydrogeologii. T. 13, cz. 3, Wydział Geologii, Geofizyki i Ochrony Środowiska AGH, Kraków, 617-623.

Wagner J., 2000. Mapa hydrogeologiczna Polski w skali 1: 50 000. Arkusz 972 Krzeszowice. Państwowy Instytut Geologiczny, Warszawa.

Wątor K., 2014. Przestrzenno-czasowa analiza zmienności składu chemicznego wód leczniczych rejonu Buska-Zdroju. Wydział Geologii, Geofizyki i Ochrony Środowiska AGH, Kraków [Ph.D. thesis, unpublished].

Wątor K., 2015. Ocena leczniczego charakteru wód z wykorzystaniem niepewności pomiaru w wodach uzdrowiska Busko-Zdrój. Technika Poszukiwań Geologicznych. Geotermia, Zrównoważony Rozwój, 2, 79-88.

Wątor K., Kmiecik E. \& Tomaszewska B., 2016. Assessing medicinal qualities of groundwater from the Busko-Zdrój area (Poland) using the probabilistic method. Environmental Earth Sciences, 85, 9, 804, 1-13. 